\title{
Magnesium use in pre-sowing treatment of spring wheat seeds
}

\author{
Venera Ramazanova* \\ Tyumen Scientific Center of the Siberian Branch of the Russian Academy of Sciences, 86 Malygina \\ St., Tyumen, Russia, 625026
}

\begin{abstract}
Studies of different content of magnesium nanoparticles in combination with stabilizers polyvinylpyrrolidone (PVP) and collagen hydrolyzate (GC) on the effect on the growth processes of spring wheat plants were conducted. It was found that the most positive effect on germination was produced by magnesium preparations in the following concentrations $\mathrm{Mg} 10 \mathrm{mg}$ + PVP with a rate of $5 \mathrm{ml} / \mathrm{t}, \mathrm{Mg} 20 \mathrm{mg}+\mathrm{PVP}$ with a rate of $1 \mathrm{ml} / \mathrm{t}, \mathrm{Mg} 10 \mathrm{mg}+$ $\mathrm{GC}$ with a rate of $1 \mathrm{ml} / \mathrm{t}$. The initial growth and development of the root was significantly affected by the variant №3 $\mathrm{Mg} 10 \mathrm{mg}+\mathrm{Ag} 1$ $\mathrm{ml}+$ PVP at the rate of $1 \mathrm{ml} / \mathrm{t}$, and the development of the sprout was affected by all magnesium nanosets at the rate of $1 \mathrm{ml} / \mathrm{t}$. When analyzing the assessment of plant development on days 7, 10 and 15 , it was found that magnesium preparations with collagen stabilizer (GC) had a positive effect. Treatment with magnesium preparations on vegetative parts of plants, namely daily sprouts determined the effective rate of the preparation of $5 \mathrm{ml}$ and more. The high values were in the variants $\mathrm{Mg} 20 \mathrm{mg}+\mathrm{PVP}, \mathrm{Mg} 10 \mathrm{mg}$ $+\mathrm{Ag} 1 \mathrm{ml}+\mathrm{GC}$, where the increase in sprout length was 2.7-2.9 $\mathrm{cm}$, weight 1.0-1.3 g.
\end{abstract}

\section{Introduction}

The use of microfertilizers is an important part of measures to increase crop yields, since the use of only mineral and organic fertilizers is not enough for normal plant development [1]. Micronutrients belong to the group of irreplaceable nutrients and play a multifaceted role in plant life: they participate in biochemical and physiological processes, activate the activity of enzymes, vitamins, hormones, as well as increase the productivity of crops [2]. In addition, trace elements increase the resistance of plants to adverse environmental conditions and increase their immunity to bacterial and fungal diseases [3]. Micronutrient deficiency disturbs the normal metabolism of plants, which leads to external changes in the structure of leaves and stems, their shape, color, the appearance of areas of dead tissues of different colors and a number of other changes [4]. Magnesium $(\mathrm{Mg})$ is an essential and

\footnotetext{
*Corresponding author: hasanova.venera.96@mail.ru
} 
nutritious trace element [5]. The content of magnesium in plants is on average $0.07 \%$ of their weight [6]. Magnesium accelerates seed ripening and affects their quality, also affects the formation of inflorescences and fruits, precocity and uniformity of maturity, contributes to an increase in crop quality. In turn, the lack of magnesium in the plant nutrition causes a violation of their assimilation of nitrogen, potassium and calcium, which negatively affects the size and quality of yield, as well as the development of leaf chlorosis [7, 8]. Magnesium sulfate (epsomite), a fast-acting fertilizer containing $17.7 \%$ magnesium oxide and $13.5 \%$ sulfur, is most commonly used. as a magnesium-containing fertilizer [9]. Magnesium nanoparticles help to increase crop yields [10].

The aim of the study is to determine the effectiveness of the application of magnesium nanoforms on the initial growth and development of spring wheat plants.

\section{Materials and Methods}

Studies, were carried out under laboratory conditions in the Research Institute of Agriculture of the Northern Trans-Urals Region in 2020. Magnesium nitrate 6-water magnesium, was taken as a source of magnesium. A total of 6 samples were used in the experiments.

1. Mg 1. Magnesium content $10 \mathrm{mg} / \mathrm{ml}$.

2. Mg 3. Bimetallic sample (magnesium with silver addition), stabilized (Stabilizer polyvinylpyrrolidone (PVP);

3. Mg 2. Magnesium content $20 \mathrm{mg} / \mathrm{ml}$. Stabilizer polyvinylpyrrolidone (PVP). Magnesium content $10 \mathrm{mg} / \mathrm{ml}$, silver content $1 \mathrm{mg} / \mathrm{ml}$;

4. Mg 4. Magnesium content $10 \mathrm{mg} / \mathrm{ml}$, stabilized with collagen hydrolysate (GC);

5. Mg 5. Magnesium content $20 \mathrm{mg} / \mathrm{ml}$, stabilized with collagen hydrolysate (GC);

6. Mg 6. Bimetallic sample (magnesium with silver addition) stabilized with collagen hydrolysate. Magnesium content $10 \mathrm{mg} / \mathrm{ml}$, silver content $1 \mathrm{mg} / \mathrm{ml}$;

7. Control - distilled water

Germination was determined according to GOST 12038-84. Phytoexpertise of seeds was carried out by roll method of 50 grains in 4 repetitions. Seeds were treated with the presented preparations at the rate of a ready-made solution per $100 \mathrm{~g}$ of seeds with an exposure of 1 hour, followed by seeding into Petri dishes and filter paper rolls and into the sand to evaluate development for 15 days. To analyze the effect of preparations on living plant, we treated germinated wheat grains for a day with the preparation and planted 20 pieces in a plastic container. Development was observed for 7 days, and the length and weight of vegetative organs were counted at the end. The assessment of the seed material infestation by various pathogens was assessed on the 7 th day. Seeds of spring wheat variety Omskaya 36 were taken for the experiment.

\section{Results and discussion}

In the course of studies of the application of different variations of the preparation containing magnesium in the treatment of spring wheat seeds, the effect on germination and development of plants on days 7, 10, 15 was determined. The highest percentage of germination $82 \%$, was established in the variant № $4 \mathrm{Mg} 10 \mathrm{mg} / \mathrm{ml}$ stabilized collagen hydrolysate (GC) at the rate of $1 \mathrm{ml} / \mathrm{t}$, which exceeds the control variant by $12 \%$. Also positive effect on the germination rate of 4-6\% was shown by the variant № $1 \mathrm{Mg} 10$ $\mathrm{mg} / \mathrm{ml}+(\mathrm{PVP})$ at the rate of $5 \mathrm{ml} / \mathrm{t}$, variant № $2 \mathrm{Mg} 20 \mathrm{mg} / \mathrm{ml}+(\mathrm{PVP})$ at the rate of $1 \mathrm{ml} / \mathrm{t}$. The most convenient concentration of $10 \mathrm{mg}+\mathrm{PVP}$ with a rate of $5 \mathrm{ml} / \mathrm{t}$ and $20 \mathrm{mg}+\mathrm{PVP}$ with a rate of $1 \mathrm{ml} / \mathrm{t}$, and $10 \mathrm{mg}+\mathrm{GC}$ with a rate of $1 \mathrm{ml} / \mathrm{t}$ are determined. Application of 
magnesium in lower content in the solution together with collagen hydrolyzate is determined by the effect of the stabilizer on the penetration of the working fluid solution with the trace element into the seed and the initial phases of plant growth. Application of magnesium with silver and at $20 \mathrm{mg} \mathrm{s}(\mathrm{GC})$ increased the negative effect at these rates of application, reduced germination by $2-13 \%$. In these variations it is necessary to reduce the application rate to $0.5 \mathrm{ml} / \mathrm{t}$. The morphological development of the plant in the first phases of ontogenesis emphasizes how quickly the plant will pass this phase, due to the increased growth of the roots and the above-ground part. Magnesium $10 \mathrm{mg} / \mathrm{ml}$ with silver additive, stabilized PVP produced the best results in root length and root weight with values of 8.6 $\mathrm{cm}$ and $2.84 \mathrm{~g}$. Also, root development was affected by option №1 $\mathrm{Mg} 10 \mathrm{mg}+$ PVP with a rate of $5 \mathrm{ml}$ and option № $4 \mathrm{Mg} 10 \mathrm{mg}+\mathrm{GC}$ with a rate of $1 \mathrm{ml}$. Sprout development was positively influenced by all variants with the rate of $1 \mathrm{ml} / \mathrm{t}$ stimulating the sprout length by 1.1-2.1 cm above the control. Among them, the highest index reached $12.1 \mathrm{~cm}$ with magnesium $20 \mathrm{mg} / \mathrm{ml}$, stabilized with collagen hydrolysate (GC). The smallest sprout length of 3.09 was with magnesium $20 \mathrm{mg} / \mathrm{ml}$, stabilized with PVP. The sprout weight relative to the control was at or below the level. Coleoptile length in all variants had a restraining development by $0.5-1.2 \mathrm{~cm}$ relative to the control variant (Table 1).

Table 1. Development of spring wheat plants on the 7 th day after treatment of seeds with magnesium nano-substances

\begin{tabular}{|c|c|c|c|c|c|c|}
\hline Option & $\begin{array}{c}\text { Germination, } \\
\text { \%o }\end{array}$ & $\begin{array}{c}\text { Root } \\
\text { length, } \\
\text { cm }\end{array}$ & $\begin{array}{c}\text { Coleoptile } \\
\text { length, cm }\end{array}$ & $\begin{array}{c}\text { Sprout } \\
\text { length, cm }\end{array}$ & $\begin{array}{c}\text { Sprout } \\
\text { weight, g }\end{array}$ & $\begin{array}{c}\text { Weight of } \\
\text { the root, g }\end{array}$ \\
\hline No.1 norm 1 ml/t & 68 & $\mathbf{7 , 5}$ & 4,8 & 11,8 & 7,11 & 2,14 \\
\hline No. 1 norm 5 ml/t & $\mathbf{7 6}$ & $\mathbf{8 , 4}$ & 4,9 & 10,87 & 7,94 & 2,34 \\
\hline No. 2 norm 1 ml/t & $\mathbf{7 4}$ & 7,4 & 4,5 & 11,2 & 6,81 & 2,40 \\
\hline No.2 norm 5 ml/t & 57 & 6,8 & 4,4 & 3,09 & 5,11 & 0,23 \\
\hline No. 3 norm 1 ml/t & 66 & $\mathbf{8 , 6}$ & 4,8 & 11,4 & 6,93 & 2,84 \\
\hline No. 3 norm 5 ml/t & 58 & 6,2 & 4,7 & 4,15 & 6,70 & 0,47 \\
\hline No. 4 norm 1 ml/t & $\mathbf{8 2}$ & $\mathbf{7 , 8}$ & 4,7 & 11,1 & 6,97 & 2,04 \\
\hline No. 4 norm 5 ml/t & 54 & 7,1 & 3,6 & 5,91 & 5,18 & 0,92 \\
\hline No. 5 norm 1 ml/t & 70 & 7,5 & 4,9 & 12,1 & 6,97 & 2,28 \\
\hline No. 5 norm 5 ml/t & 60 & 6,7 & 3,6 & 6,5 & 5,50 & 0,90 \\
\hline No. 6 norm 1 ml/t & 68 & 6,8 & 4,9 & 11,6 & 7,35 & 2,70 \\
\hline No. 6 norm 5 ml/t & 66 & 7,4 & 4,2 & 9,7 & 5,84 & 1,0 \\
\hline 0. Control & 70 & 7,5 & 5,4 & 10 & 7,8 & 2,25 \\
\hline
\end{tabular}

The development of plants for 15 days under any influence shows the tendency of the reception to influence the formation of the plant in the initial period, when there is a growth of green mass, the establishment of secondary shoots and the beginning of tillering of the crop. Germination, was determined by the average data on 7, 10 and 15 days. Thus, the variants of experience are $4-12 \%$ higher than the control, the most active effect on increasing germination in the sand was produced by preparations containing $\mathrm{Mg} 20 \mathrm{mg}+$ PVP and Mg 10-20 mg + GC, where a clear reliable increase in germination of spring wheat seeds at all application rates is observed, but more so at the rate of $1 \mathrm{ml} / \mathrm{t}$. On day 7 of observation in terms of sprout length and sprout weight, magnesium $10 \mathrm{mg} / \mathrm{ml}$ stabilized PVP had a significant effect with results of $15.34 \mathrm{~cm}$ and $7.9 \mathrm{~cm}$, which exceeded the control by $2.44 \mathrm{~cm}$ and $2.48 \mathrm{~cm}$, respectively. In terms of root length we can distinguish three variants (№ 1, № 2, № 6), which were at the level of the control variant with a length index of $11 \mathrm{~cm}$. The highest weight of roots was observed with magnesium $20 \mathrm{mg} / \mathrm{ml}+$ PVP, Mg $10 \mathrm{mg}+\mathrm{GC}, \mathrm{Mg} 20 \mathrm{mg}+\mathrm{GC}$ at the rate of $5 \mathrm{ml} / \mathrm{t}$, which is higher than the control variant by 3.3-4.2 g. On the 10th day the development of sprouts reached $19-21 \mathrm{~cm}$ not exceeding the control in length, and all variants stood out by weight with the rate of 1 
$\mathrm{ml} / \mathrm{t}$, which is higher than the control by $0.7-2 \mathrm{~g}$. Increase in root length was $1-3 \mathrm{~cm}$ over 3 days and the figures reached $12-15 \mathrm{~cm}$, relative to control. Increase in root length was 1-3 $\mathrm{cm}$ in all variants and their norms, the weight of the roots was at the level of control or lower.

On day 15, plant growth was slower than on day 1 of development and was $21-24 \mathrm{~cm}$ with a greater increase in stem length for the variants of magnesium with (GC). Root length in laboratory conditions also had a slight increase compared to previous count dates. The excess of control was $13-17 \mathrm{~cm} \mathrm{~s}$ in most variants at the rate of $1 \mathrm{ml} / \mathrm{t}$ and with a greater effect when magnesium, was applied in mixture with (GC), where the increase in length was 2-4 cm, but the value of root mass had no dependence on treatment (Table 2).

Table 2. Plant development of spring wheat Omskaya 36 in the dynamics of 15 days.

\begin{tabular}{|c|c|c|c|c|c|c|c|}
\hline \multirow[b]{2}{*}{ Option } & \multirow{2}{*}{$\begin{array}{c}\text { Germi } \\
\text { nation, } \\
\% \%\end{array}$} & \multicolumn{3}{|c|}{ Sprout length/sprout weight } & \multicolumn{3}{|c|}{ Root length/root weight } \\
\hline & & $\begin{array}{c}7 \\
\text { hours }\end{array}$ & $\begin{array}{c}10 \\
\text { hours }\end{array}$ & $\begin{array}{c}15 \\
\text { hours }\end{array}$ & $\begin{array}{c}7 \\
\text { hours }\end{array}$ & $\begin{array}{c}10 \\
\text { hours }\end{array}$ & $\begin{array}{c}15 \\
\text { hours }\end{array}$ \\
\hline 0. control & 75,6 & $12,9 / 5,42$ & $21,5 / 8,30$ & $23,3 / 9,09$ & $11 / 5,14$ & $12 / 5,84$ & $13 / 8,63$ \\
\hline No. 1 norm $1 \mathrm{ml} / \mathrm{t}$ & 76,6 & $14,37 / 7,4$ & $21,6 / 10,3$ & $22,1 / 10,0$ & $10,0 / 8,1$ & $13,0 / 5,2$ & $15,0 / 10,3$ \\
\hline +-to counter. & $+1,6$ & $1,47 / 1,98$ & $0,1 / 2$ & $-1,2 / 0,91$ & $-1,5 / 2,96$ & $+1 /-0,64$ & $+2 /+1,67$ \\
\hline No. 1 norm $5 \mathrm{ml} / \mathrm{t}$ & 66,6 & $15,34 / 7,9$ & $19,3 / 8,8$ & $21,5 / 8,5$ & $11 / 2,04$ & $14 / 4,4$ & $14 / 4,00$ \\
\hline +-to counter. & $-9,0$ & $2,44 / 2,48$ & $-2,2 / 0,5$ & $-1,8 /-0,59$ & $0 /-3,1$ & $+2 /-1,44$ & $+1 /-4,63$ \\
\hline No. 2 norm $1 \mathrm{ml} / \mathrm{t}$ & 83,3 & $13,59 / 6,6$ & $21,2 / 9,22$ & $21,7 / 9,00$ & $10 / 7,82$ & $13 / 1,28$ & $15 / 4,06$ \\
\hline +-to counter. & $+7,7$ & $0,69 / 1,18$ & $-0,3 / 0,92$ & $-1,6 /-0,09$ & $-1 / 2,68$ & $+1 /-4,56$ & $+2 /-4,57$ \\
\hline No. 2 norm $5 \mathrm{ml} / \mathrm{t}$ & 88,3 & $12,36 / 6,1$ & $18,76 / 8,2$ & $20,6 / 7,11$ & $11 / 8,77$ & $15 / 3,58$ & $10 / 6,5$ \\
\hline +-to counter. & $+12,7$ & $\begin{array}{c}- \\
0,54 / 0,68\end{array}$ & $-2,74 /-0,1$ & $-2,7 /-1,98$ & $0 / 3,63$ & $+3 /-2,26$ & $-3 /-2,13$ \\
\hline No. 3 norm $1 \mathrm{ml} / \mathrm{t}$ & 81,6 & $13,38 / 6,4$ & $19,4 / 9,11$ & - & $10 / 7,41$ & $14 / 3,64$ & - \\
\hline +-to counter. & $+6,0$ & $0,48 / 0,98$ & $-2,1 / 0,81$ & - & $-0,3 / 2,27$ & $+2 /-2,2$ & - \\
\hline No. 3 norm $5 \mathrm{ml} / \mathrm{t}$ & 81,6 & $12,30 / 5,9$ & $20,4 / 8,63$ & - & $9 / 6,05$ & $13 / 3,52$ & - \\
\hline +-to counter. & $+6,0$ & $-0,6 / 0,48$ & $-1,1 / 0,33$ & - & $-2 / 0,91$ & $+1 /-2,32$ & - \\
\hline No. 4 norm $1 \mathrm{ml} / \mathrm{t}$ & 85,0 & $13,36 / 6,9$ & - & - & $9 / 8,5$ & - & - \\
\hline +-to counter. & $+9,4$ & $0,46 / 3,58$ & - & - & $-2 / 3,36$ & - & - \\
\hline No. 4 norm $5 \mathrm{ml} / \mathrm{t}$ & 80,0 & $13,48 / 7,0$ & - & $24,4 / 10,4$ & $10 / 7,71$ & - & $15 / 9,58$ \\
\hline +-to counter. & $+4,4$ & $0,58 / 1,58$ & - & $1,1 / 1,31$ & $-1 / 2,57$ & - & $+2 / 0,95$ \\
\hline No. 5 norm $1 \mathrm{ml} / \mathrm{t}$ & 98,3 & $14,34 / 7,2$ & $19,11 / 8,7$ & $24,5 / 10,7$ & $9 / 7,89$ & $14 / 4,89$ & $17 / 7,04$ \\
\hline +-to counter. & $+22,7$ & $1,44 / 1,78$ & $-2,39 / 0,4$ & $1,2 / 1,61$ & $-2 / 2,75$ & $+2 /-0,95$ & $+4 /-1,59$ \\
\hline No. 5 norm $5 \mathrm{ml} / \mathrm{t}$ & 90,0 & $13,26 / 6,4$ & $19,8 / 8,05$ & $21,7 / 5,83$ & $10 / 9,36$ & $14 / 2,23$ & $14 / 8,16$ \\
\hline +-to counter. & $+14,4$ & $0,36 / 0,98$ & $-1,7 /-0,25$ & $-1,6 /-3,26$ & $-1 / 4,22$ & $+2 /-3,61$ & $+1 /-0,47$ \\
\hline No. 6 norm $1 \mathrm{ml} / \mathrm{t}$ & 93,3 & $13,03 / 6,4$ & $19,95 / 9,2$ & $23,06 / 9,6$ & $11 / 8,45$ & $15 / 4,89$ & $16 / 7,0$ \\
\hline +-to counter. & $+17,7$ & $0,13 / 0,98$ & $-1,55 / 0,9$ & $\begin{array}{c}- \\
0,24 / 0,51\end{array}$ & $0 / 3,31$ & $+3 /-0,95$ & $+3 /-1,63$ \\
\hline No. 6 norm $5 \mathrm{ml} / \mathrm{t}$ & 85,0 & $12,48 / 6,4$ & $18,6 / 9,00$ & $25,05 / 11$ & $9 / 7,75$ & $14 / 3,07$ & $13 / 5,70$ \\
\hline +-to counter. & $+9,4$ & $\begin{array}{c}- \\
0,42 / 0,98\end{array}$ & $-2,9 / 0,7$ & $1,75 / 1,91$ & $-2 / 2,61$ & $+2 /-2,77$ & $0 /-2,93$ \\
\hline
\end{tabular}

Treatment of daily sprouts with magnesium preparations and their further germination in Petri dishes for 7 days showed a positive effect of magnesium on the development of spring wheat plants. The results clearly show that the most convenient and positive rate for plant development is $5 \mathrm{ml} / \mathrm{t}$ in all variants, except variant № $5 \mathrm{Mg} 20 \mathrm{mg}+\mathrm{GC}$, where 
collagen hydrolysate enhances the entry of the drug into the plant and it is possible that the dose of magnesium $20 \mathrm{mg}$ in the solution together with GC exceeds the necessary for the plant. The best results were obtained when treating sprouts with magnesium at the rate of 5 $\mathrm{ml} / \mathrm{t}$ in the variants $\mathrm{Mg} 20 \mathrm{mg}+\mathrm{PVP}, \mathrm{Mg} 10 \mathrm{mg}+\mathrm{Ag} 1 \mathrm{ml}+\mathrm{HA}$, where the increase in sprout length was 2.7-2.9 cm, weight 1.0-1.3 g (Table 3).

Table 3. Effect of treatment of daily sprouts with magnesium preparations.

\begin{tabular}{|c|c|c|}
\hline Option & Sprout length, cm & Weight of 200 sprouts, $g$ \\
\hline No. 1 norm $1 \mathrm{ml} / \mathrm{t}$ & $8,45(+0,83)$ & $4,52(+0,15)$ \\
\hline No. 1 norm $5 \mathrm{ml} / \mathrm{t}$ & $9,57(+1,95)$ & $5,10(+0,73)$ \\
\hline No. 2 norm $1 \mathrm{ml} / \mathrm{t}$ & $8,52(+0,9)$ & $5,10(+0,73)$ \\
\hline No. 2 norm $5 \mathrm{ml} / \mathrm{t}$ & $10,57(+2,95)$ & $5,68(+1,31)$ \\
\hline No. 3 norm $1 \mathrm{ml} / \mathrm{t}$ & $7,29(-0,33)$ & $4,12(-0,25)$ \\
\hline No. 3 norm $5 \mathrm{ml} / \mathrm{t}$ & $9,07(+1,45)$ & $4,90(+0,53)$ \\
\hline No. 4 norm $1 \mathrm{ml} / \mathrm{t}$ & $7,28(-0,34)$ & $4,25(-0,12)$ \\
\hline No. 4 norm $5 \mathrm{ml} / \mathrm{t}$ & $9,25(+1,63)$ & $5,15(+0,78)$ \\
\hline No. 5 norm $1 \mathrm{ml} / \mathrm{t}$ & $7,82(+0,2)$ & $3,97(-0,4)$ \\
\hline No. 5 norm $5 \mathrm{ml} / \mathrm{t}$ & $7,42(-0,2)$ & $3,90(-0,47)$ \\
\hline No. 6 norm $1 \mathrm{ml} / \mathrm{t}$ & $10,4(+2,78)$ & $5,60(+1,23)$ \\
\hline No. 6 norm $5 \mathrm{ml} / \mathrm{t}$ & $10,34(+2,72)$ & $5,40(+1,03)$ \\
\hline 0. Control & 7,62 & 4,37 \\
\hline
\end{tabular}

\section{Conclusions}

As a result, the most active options affecting the germination of $\mathrm{Mg} 10 \mathrm{mg}+\mathrm{PVP}$ with a rate of $5 \mathrm{ml} / \mathrm{t}, \mathrm{Mg} 20 \mathrm{mg}+\mathrm{PVP}$ with a rate of $1 \mathrm{ml} / \mathrm{t}, \mathrm{Mg} 10 \mathrm{mg}+\mathrm{GC}$ with a rate of $1 \mathrm{ml} / \mathrm{t}$ were determined. Root development was intensified by the variant № $3 \mathrm{Mg} 10 \mathrm{mg}+\mathrm{Ag} 1$ $\mathrm{ml}+\mathrm{PVP}$ at a rate of $1 \mathrm{ml} / \mathrm{t}$, the sprout development was influenced by all variants at a rate of $1 \mathrm{ml} / \mathrm{t}$ increasing its length by $1.1-2.1 \mathrm{~cm}$ and limited the growth of coleoptile by $0.5-1.2$ $\mathrm{cm}$.

Assessment of plant development in the dynamics of 15 days shows the effect of variants with magnesium and their rates on plant growth. Germination increased by $4-12 \%$ when Mg $20 \mathrm{mg}+$ PVP, Mg 10-20 mg + GC to a greater extent at the rate of $1 \mathrm{ml} / \mathrm{t}$. Analysis of plants shows that a pronounced effect is noticeable on day 7, and further the influence of the drug weakens, and the next possible application for growth regulation is necessary in the phase of tillering in conjunction with herbicide treatment. The most pronounced effect in all phases of observation is noted for the variants of magnesium with (GC).

Magnesium treatment of vegetative parts of plants, namely daily sprouts, determined the effective rate of the drug $5 \mathrm{ml}$ or more, high rates for the variants $\mathrm{Mg} 20 \mathrm{mg}+\mathrm{PVP}, \mathrm{Mg} 10$ $\mathrm{mg}+\mathrm{Ag} 1 \mathrm{ml}+\mathrm{GC}$, where the increase in sprout length was $-2.7-2.9 \mathrm{~cm}$, weight $-1.0-1.3$ g.

\section{Acknowledgements}

Work performed under the state order № 121041600036-6 


\section{References}

1. D.V. Syshchikov, S.A. Prikhodko [et al.], Environmental Conference, March 26-27, Krasnodar, 589-591 (2019)

2. S.A. Semina, N.I. Ostroborodova, Journal Niva Povolzhya, 2 (55), 40-45, (2020)

3. I.R. Wildflush, O.I. Mishura, S.R. Chuiko, Vestnik of the Belarusian GSA, 1, 23-27 (2018)

4. V.V. Popova, N.V. Goman, I.A. Bobrenko, A.A. Gaidar, Vestnik KRASGAU., 8 (161), 57-64 (2020)

5. Cristiane SEGATTO, Clovis Arruda SOUZA, Cristiano Reschke LAJÚS, Márcio Antônio FIORI, Luciano Luiz SILVA, Humberto Gracher RIELLA, Cileide Maria Medeiros COELHO, AJCS 14 (09), 1473-1478 (2020) doi: 10.21475/ajcs.20.14.09.p2558

6. A.A. Neverov, Izvestiya Orenburgskogo GAU 1, 74-78 (2021)

7. FGBNU VNII agrochemistry method, 27 (Moscow, 2017)

8. G.N. Nenaidenko, T.V. Sibiryakova, Vladimir Landowner Magazine, 2 (80), 22-23 (2017)

9. A.P. Dolmatov, I.V. Vasiliev, A.P. Tomin [et al.] Izvestiya Orenburgskogo GAU, 6, 74-76 (2019)

10. Rathore, Indira; Tarafdar, J. C., Journal of Bionanoscience, 9, 3, (6) 209-214 (2015) doi: https://doi.org/10.1166/jbns.2015.1296

11. GOST 12038-84. Seeds of agricultural crops. Methods of analysis. SB. GOSTs. Moscow: Publishing, Standards, 2004. 47 c. 